S. G. Kovalenko, Ph.D., assistant professor,

T. V. Vasylyeva ${ }^{1}$, Ph.D., assistant professor

O. Yu. Bondarenko, Ph.D., assistant professor

V. V. Nemertsalov ${ }^{2}$, Ph.D., assistant professor

Odesa Mechnikov National University, Department of Botany

2, Dvorianska str., Odesa 65082, Ukraine, e-mail: tvas@ukr.net' ${ }^{1}$; wism@ukr.net ${ }^{2}$

\title{
THE SPECIMENS OF FAMOUS BOTANIST MICHEL GANDOGER IN MSUD HERBARIUM (to the celebration of the year of France in
}

Ukraine)

The thesis described the part of the historical collection of ONU (MSUD) herbarium. Specimens, gathered in the South of France in 1895-1898 by the famous French botanists Michel Gandoger, preserved in the herbarium of E.E. Lindemann were analyzed. There are 332 samples of Gandoger's collection from Rhone and Arnas. The systematical list contains 60 families, 198 genera, 318 species, and 26 forms. In addition, 14 species from 10 families, which were described by Gandoger are presented in MSUD herbarium. His life way and scientific achievements in investigation of the Mediterranean flora were emphasized.

Keywords: herbarium of Odesa National Mechnykov University (MSUD); history of science; Michel Gandoger.

The role of historical herbariums is not only in the study of flora and vegetation, but also in the possibility to study the history of science and biography of scientists. It helps us to imagine the collector, his endeavor, yearning, passion for his deals. These collections are essential in establishing scientific priorities and the correct name of the plant. Significant herbarium collections often allow making the acquaintance with such persons, to see the extensive work, which lies not only for collection but also for attribute the material.

The aim of our investigation was the analysis of herbarium collections of French scientist M. Gandoger presented in MSUD herbarium. The herbarium received the status of a national treasure of Ukraine in 2004. More information about the herbarium (its structure and history) you can find on the website [11]. In honor of the year of France in Ukraine (2019), it was interesting to analyze herbarium collections of one of the famous French botanists of the XIX century, kept in ONU.

The problem of the investigation included systematical analysis of species, kept in MSUD collection, reveal the places of plant collection, and indicate the biographical information about M. Gandoger's life and scientific work. 


\section{Materials and methods}

Materials for investigation were herbarium collections of $\mathrm{M}$. Gandoger, as a part of historical herbarium MSUD "Collection of E. E. Lindemann". E. Lindemann corresponded with many botanists and botanical societies and was engaged in an active herbarium exchange. Due to this fact, his collection is of a particular value. Herbarium specimens were probably obtained from Gandoger in the same way.

We used classical, generally known methods of herbarium collection analysis in the work. Plants on the 332 herbarium' sheets, made by the scientist in 1895-1898 in the south of France were analyzed. Their names and taxonomy are indicated by the nomenclature of those times. The names of settlements are quoted by information from the labels. We also used the biographical materials of scientists and indicated the most important facts from his life in chronological order.

\section{Results and their discussion}

Biographical Information. The famous French botanists, mycologist, and doctor - Jean Michel Gandoger - (10.V.1850-4.X.1926) was born in Arnas in the family of wealthy owners of vineyards in Bogole and passed away in Lion (fig.1).

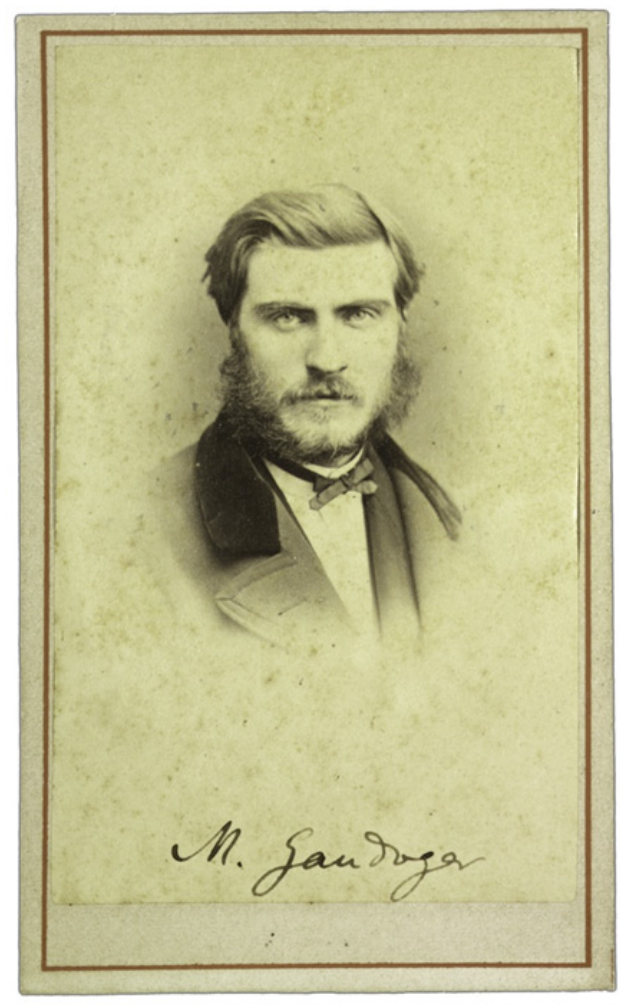

Fig. 1. M. Gandoger, 1876 [3] 
M. Gandoger became interested in botany at the age of fifteen. Due to the support of his family (his mother and aunt helped him in this hobby) by the age of twenty he became the owner of an extensive herbarium collection, as well as the author of botanical publications. He was a brilliant autodidact and amator, who willingly learned from contemporaries and predecessors [10]. Gandoger graduated the theological seminary, but as a priest worked only one year in Tizzi-Ouzoce (Algeria) and then returned to Arnas. He devoted his life to studying the Mediterranean flora, especially of Spain, where he made 24 scientific journeys and was considered to be one of the most careful investigators of this region in XIX cent. In 1874 he published materials about South East of the Mediterranean. In 1876 he began to investigate genus Rosa and became its famous specialist. Besides Spain, he gathered the herbarium in Greece, Portugal and Algeria. In 1883-1891 he prepared European flora in 27 volumes, then a monograph about family Cruciferae in the world (25000 species, three volumes). Gandoger published a description of 1001 species of plants, which they were not meet before. The list of his principal works was published in "Bulletin" of the French botanical society by padre J. B. Charbonnel in 1927 (v.74. p. 3-11). Besides Magnoliophyta, Gandoger paid attention to ferns and mushrooms. He described and gave the names to many species from different families $[6,8,9]$. The herbarium of world plants he gathered had 800 thousand sheets in 5000 cardboards, which have not survived to our time. The abbot's personal wealth and income allowed him to finance both botanical expeditions and the acquisition of exotic herbarium collections [10].

At his will, the entire herbarium after his death is stored in Lion's botanical garden [6]. Eleven species of plants were named after him in XX century: Mulinum gandogeri M. Hiroc. (from 1979 - M. Gandogerii), Anthurium gandogeri Sodiro (1909), Hieracium gandogeri (Zahn.) Zahn., Sonchus gandogeri Pit. (1908), Halimium gandogeri Janch. (1925), Carex gandogeri H.Lev. ex Gand. (1908), Anthyllis gandogeri Sagorski (1908), Brachypodium gandogeri Hack. ex Gand. (1910), Nardurus gandogeri Gredilla (1900), Poa gandogeri Fedde (1910), Leucadendron gandogeri Schinz. ex Gand. (1918) (Gand. - Gandoger).

Herbarium collection analysis. In the historical herbarium of E. E. Lindemann, there are 332 sheets of his 1895-1898 collection from Rhone and Arnas [2]. The systematical list of plants from Gandogers herbarium, contains 60 families, 198 genera, 318 species, and 26 forms (Table 1 ).

As we can see, the herbarium includes representatives of two sections: Equsetophyta and Magnoliophyta and three classes: Equsetopsida, Liliopsida, and Magnoliopsida. In the table, the names of the families are given by the taxonomy of the XIX century. To compare the list of species in the herbarium with the modern ideas about their boundaries was not the aim of this work, but it deserves a separate study. 
Table 1

Systematical spectrum of plants from Gandoger's herbarium (332 sheets)

\begin{tabular}{|c|c|c|c|c|c|}
\hline \multirow{2}{*}{$\mathbf{N}$} & \multirow{2}{*}{ Family } & \multicolumn{4}{|c|}{ Quantity of } \\
\hline & & genus & species & forms & h.sh. \\
\hline 1 & Equisetaceae & 1 & 2 & 3 & 3 \\
\hline 2 & Aceraceaeae & 1 & 2 & & 2 \\
\hline 3 & Alismataceae & 2 & 2 & & 2 \\
\hline 4 & Amaranthaceae & 1 & 1 & & 1 \\
\hline 5 & Asclepiadaceae & 1 & 1 & & 1 \\
\hline 6 & Betulaceae & 2 & 2 & 1 & 2 \\
\hline 7 & Boraginaceae & 5 & 9 & & 9 \\
\hline 8 & Callitrichaceae & 1 & 2 & & 2 \\
\hline 9 & Campanulaceae & 1 & 2 & & 2 \\
\hline 10 & Cannabaceae & 1 & 1 & & 1 \\
\hline 11 & Caprifoliaceae & 3 & 3 & & 3 \\
\hline 12 & Caryophyllaceae & 7 & 9 & & 9 \\
\hline 13 & Celastraceae & 1 & 1 & & 1 \\
\hline 14 & Chenopodiaceae & 2 & 6 & & 6 \\
\hline 15 & Compositae & 30 & 52 & & 52 \\
\hline 16 & Convolvulaceae & 2 & 2 & 1 & 3 \\
\hline 17 & Cornaceae & 1 & 1 & & 1 \\
\hline 18 & Cuscutaceae & 1 & 1 & & 1 \\
\hline 19 & Crassulaceae & 1 & 1 & & 1 \\
\hline 20 & Cruciferae & 9 & 10 & 1 & 10 \\
\hline 21 & Cucurbitaceae & 1 & 1 & & 1 \\
\hline 22 & Dipsacaceae & 3 & 5 & & 5 \\
\hline 23 & Ericaceae & 1 & 1 & & 1 \\
\hline 24 & Euphorbiaceae & 2 & 8 & & 8 \\
\hline 25 & Fagaceae & 1 & 1 & & 1 \\
\hline 26 & Gentianaceae & 1 & 1 & & 1 \\
\hline 27 & Geraniaceae & 1 & 5 & & 5 \\
\hline 28 & Gramineae & 12 & 21 & 1 & 21 \\
\hline 29 & Guttiferae & 1 & 2 & 1 & 2 \\
\hline 30 & Hydrocharitaceae & 1 & 1 & & 1 \\
\hline 31 & Iridaceae & 1 & 1 & & 1 \\
\hline 32 & Labiatae & 14 & 22 & 5 & 24 \\
\hline 33 & Leguminosae & 14 & 31 & & 33 \\
\hline 34 & Lentibulariaceae & 1 & 1 & & 1 \\
\hline
\end{tabular}


Tables continued

\begin{tabular}{|c|c|c|c|c|c|}
\hline 35 & Liliaceae & 4 & 5 & 1 & 5 \\
\hline 36 & Lythraceae & 1 & 1 & & 1 \\
\hline 37 & Limoniaceae & 1 & 1 & & 1 \\
\hline 38 & Malvaceae & 2 & 4 & & 4 \\
\hline 39 & Moraceae & 1 & 1 & 1 & 1 \\
\hline 40 & Oleaceae & 2 & 6 & & 6 \\
\hline 41 & Onagraceae & 1 & 2 & & 1 \\
\hline 42 & Plantaginaceae & 1 & 4 & 1 & 5 \\
\hline 43 & Polygalaceae & 1 & 1 & & 1 \\
\hline 44 & Polygonaceae & 2 & 7 & 4 & 10 \\
\hline 45 & Potamogetonaceae & 1 & 1 & 1 & 1 \\
\hline 46 & Primulaceae & 3 & 3 & & 2 \\
\hline 47 & Ranunculaceae & 5 & 11 & 3 & 13 \\
\hline 48 & Rhamnaceae & 1 & 2 & & 2 \\
\hline 49 & Rosaceae & 5 & 8 & & 8 \\
\hline 50 & Rubiaceae & 2 & 6 & & 6 \\
\hline 51 & Salicaceae & 2 & 6 & 1 & 6 \\
\hline 52 & Saxifragaceae & 1 & 1 & & 1 \\
\hline 53 & Scrophulariaceae & 4 & 10 & 1 & 10 \\
\hline 54 & Solanaceae & 1 & 1 & & 1 \\
\hline 55 & Tiliaceae & 1 & 1 & & 1 \\
\hline 56 & Ulmaceae & 1 & 1 & & 1 \\
\hline 57 & Umbelliferae & 14 & 17 & & 17 \\
\hline 58 & Urticaceae & 1 & 1 & & 1 \\
\hline 59 & Valerianaceae & 1 & 1 & & 1 \\
\hline 60 & Violaceae & 1 & 1 & & 1 \\
\hline
\end{tabular}

Note: h.sh. - herbarium sheets 
The richest by the number of species and genera are families Compositae (Asteraceae) (30 g. 52 sp.), Leguminosae (Fabaceae) (14 g. 31 sp.), Labiatae (Lamiaceae) (14 g. 22 sp.), Umbelliferae (Apiaceae) (14 g. 17 sp.), Gramineae (Poaceae) (12 g. 21 sp.), Ranunculaceae (5 g. 11 sp.), Cruciferae (Brassicaceae) (9 g. 10 sp.), Scrophulariaceae (4 g. 10 sp.), Caryophyllaceae (7 g. 9 sp.), Boraginaceae (5 g. 9 sp.). There are nine families, each of which is represented by two species, and seven of them have just one genus. The number of families, which are represented by one species, is 26. From 198 genera, the richest by the number of species are Centaurea (9), Trifolium (8), Euphorbia (7), Ranunculus, and Veronica (6). Five species represent seven genera, (Chenopodium, Fraxinus, Galium, Geranium, Hieracium, Medicago, Rumex). Five genera (Bromus, Mentha, Myosotis, Plantago, Vicia) are represented by 4, and seven genera (Glyceria, Lamium, Lotus, Malva, Poa, Potentilla, Vicia) are represented by three species only. There are 31 genera represented by two species and 89 - by one species only. Twenty-six plant forms in the collection were relevant at that time, but not today.

The significant genera belong to different families. For example, in family Euphorbiaceae, there is just one genus, but family Compositae is the richest one in genera and species: Centaurea (9 species), Hieracium (5 species) and nine genera with two species. In family Leguminosae, there is one genus with eight species - Trifolium, one genus with five species - Medicago, two genera with three species - Lotus and Vicia, two genera with two species - Genista and Lathyrus. In family Labiatae 4 species belong to genus Mentha, three species - Lamium, two species - Origanum.

In the book «Plantarum Novarum praesertim ad Flora Europe stectautes» [5], there are 99 species of plants, which received their names due to Gandoger's accurate scientific description. There are 14 species of plants from 10 families named by him in MSUD herbarium. They are: Artemisia arvensis Gdgr., Batrachium arnassense Gdgr., Caltha arnasensis Gdgr., Centaurea lineata Gdgr., Erysimum arnasense Gdgr., Euphorbia vallis Gdgr., Galium Botirayanum Gdgr., Glechoma sepium Gdgr., Lamium muroreum Gdgr., Mentha asperifolia Gdgr., Potentilla nivalis Gdgr., Pulmonaria nemoricula Gdgr., Ranunculus idionanthus Gdgr., Senecio arnassensis Gdgr. Four of those species received their names in honor of M. Gandoger's native town [4, fig.2-4]. In MSUD herbarium collection there are also samples of Mentha sativa L. var. taste Link., described by him as Mentha hydrogenous Gdgr. The study of these sheets is important because they are autotypes, and can serve as types (holotypus or lectotypes) [1]. 


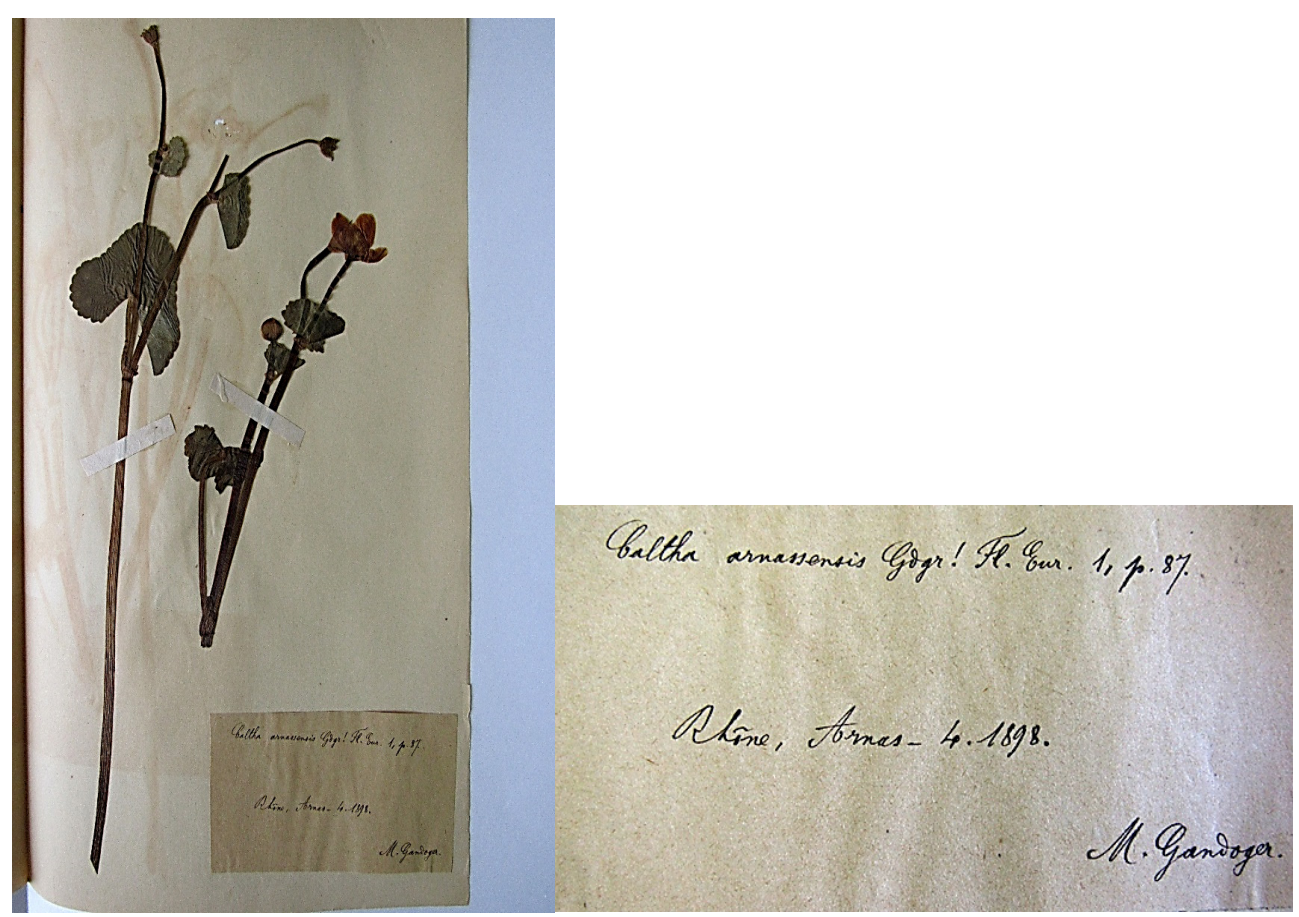

Fig.2. Herbarium sheet and label of Caltha arnassensis Gdgr., collected on Rhone, 1898

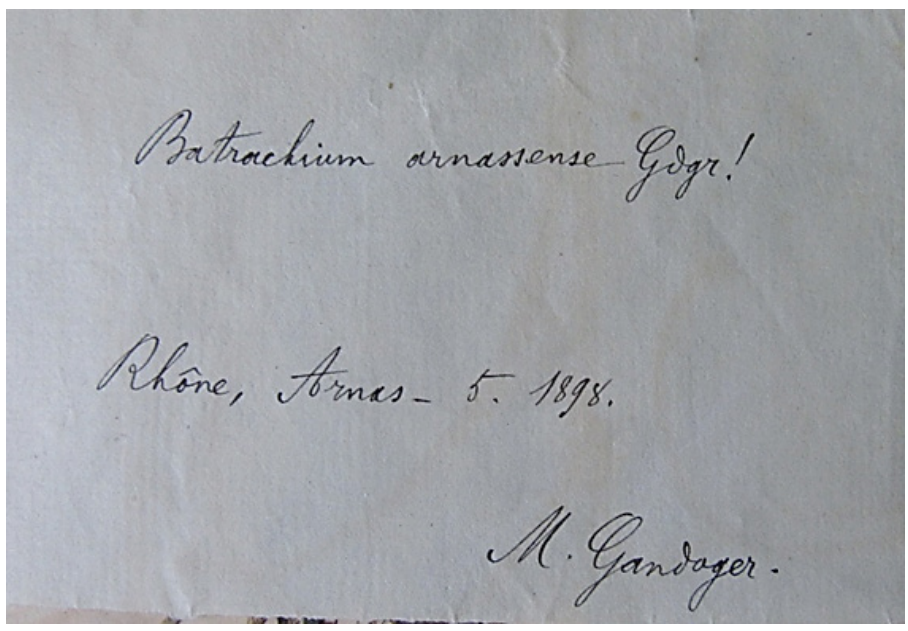

Fig.3. Label of Batrachium arnassense Grdgr., collected on Rhone, 1898 


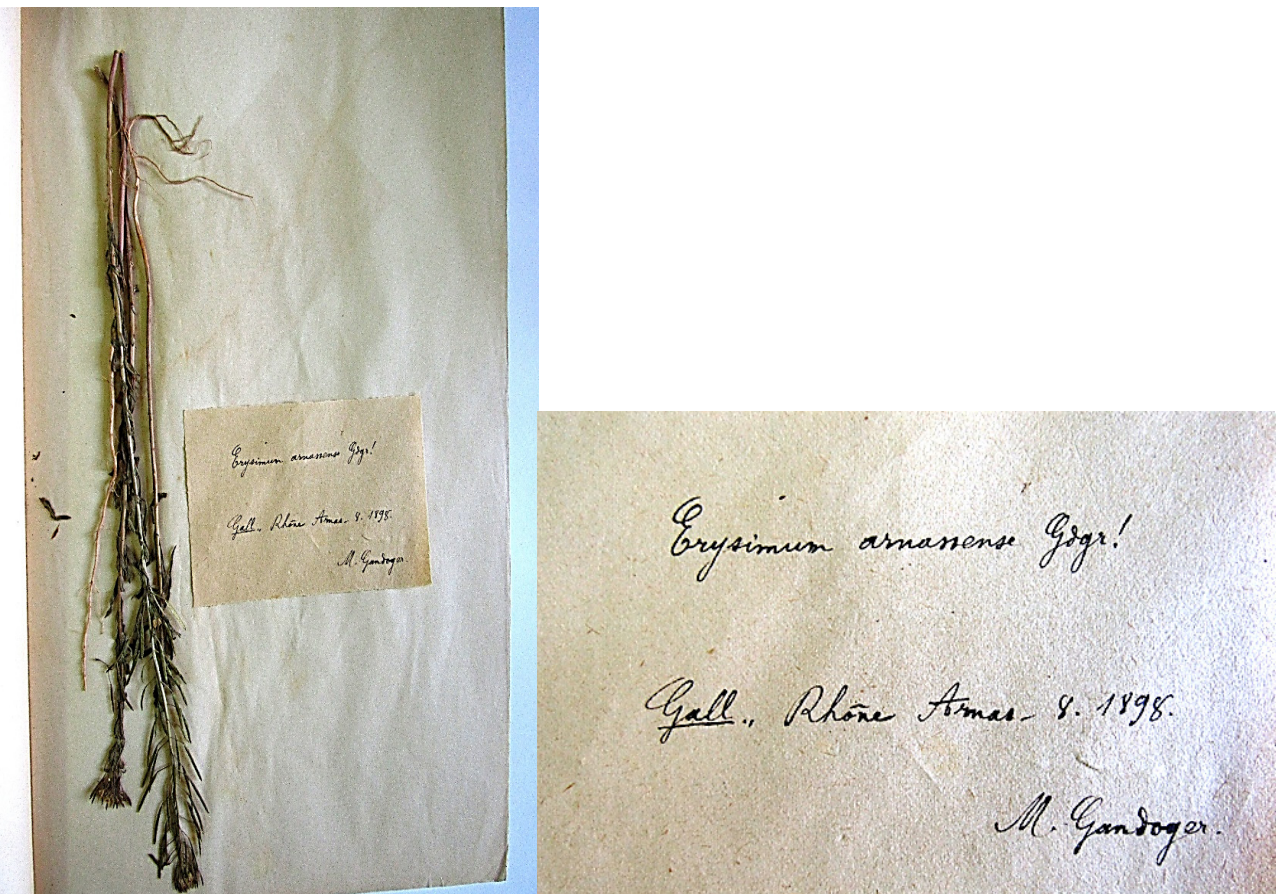

Fig. 4. Herbarium sheet and label of Erysimum arnassense Gdgr. from Rhone, 1898

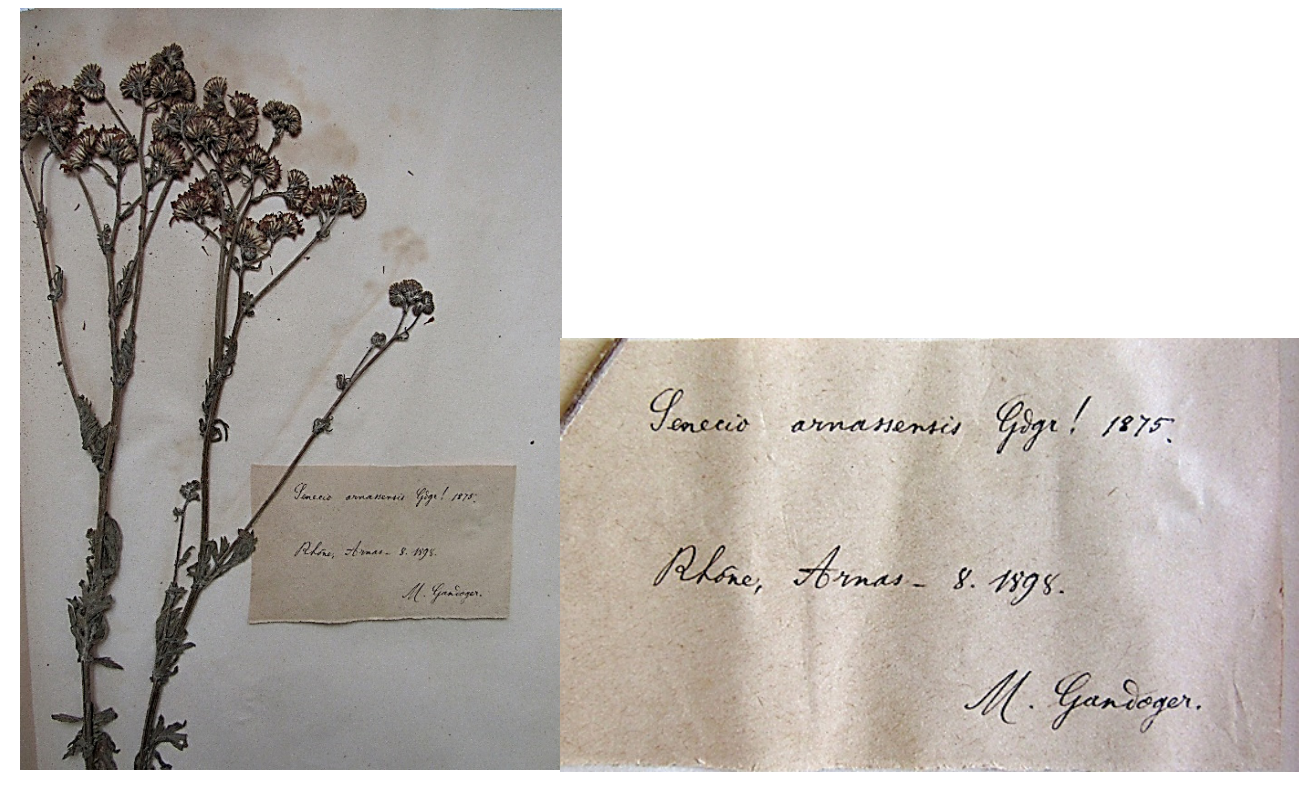

Fig. 5. Herbarium sheet and label of Senecio arnassense Gdgr., described for science in 1875, collected in 1898 
It is necessary to indicate that in the modern International Plants Names Index (IPNI) the surname of Gandoger in denominations of taxon is written as Gand. Now there are 2325 names published as Gand. The most of the species names, indicated on the labels of this collection, are absent in IPNI [9]. They have other synonyms today.

\section{Conclusion}

In this way, the future investigation of herbarium samples of MSUD collected by M. Gandoger on the South East of France at the end of XIX takes a possibility to study the Mediterranean flora, climate, and environmental conditions' changes. In our work, we tried to describe the value of M. Gandoger in studying plant species, and show his significant role in its investigation. The study of the collection revealed 14 herbarium sheets, which are autotypes.

Стаття надійшла до редакції 15.10.2019

\section{Список використаної літератури}

1. Алексеев Е. Б. Ботаническая номенклатура / Е. Б. Алексеев, И. А. Губанов, В. Н. Тихомиров. - М.: Изд-во МГУ, 1989. - 168 с.

2. Скарби гербарію ОНУ (MSUD). Гербарна колекція Е. Е. Ліндеманна / уклад.: С. Г. Коваленко, О. Ю. Бондаренко, Т. В. Васильєва, В. В. Немерцалов. - Одеса : Освіта України, 2017. $-776 \mathrm{c}$.

3. Biblioteca dell' Orto botanico, Università di Padova, Italia - URL: https://archive.org/details/M-Gandoger-recto-PHAIDRA_o_1773

4. Gandoger Michaele. Decades plantarum novarum praesertim ad floram europae spectantes. Deuxième partie publiée dans le Bulletin de la Société agricole, scientifique et littéraire des Pyrénées-Orientales, 22: 416-459. URL: https://archive.org/details/mobot31753003743520

5. Gandoger Michaele. Flora Cretica. URL: https://archive.org/details/mobot31753000530409

6. Gandoger Michaele. Flore Lyonnaise et des departaments du sud-ext comprenant l'analyse des plantes spontanées et des plantes cultivées comme industrielles ou ornementales. Paris, Lyon, 1875. 322 s. URL: https://archive.org/details/florelyonnaiseet00gand

7. Gandoger Michaele. Monograpia. Rosarum Europaea et Orientis. URL: https://archive.org/details/monographiarosar04 gand/page/n5

8. Gandoger Michaele. Novus conspectus Florae Europae. Sive enumeratio systematica Plantarum omniutn in Europa hucusque sponte cognitarum. Paris, 1910. 542 s. URL: https://archive.org/ details/novusconspectusf00gand/page/n5

9. IPNI. URL: https://www.ipni.org/a/3009-1; https://www.ipni.org/?q=author\%20std\%3AGand.

10. L'abbé J.-B. Charbonnel (1927) L'abbé Michel Gandoger, Bulletin de la Société Botanique de France, 74:1, 3-11, DOI: 10.1080/00378941.1927.10833641 https://www.tandfonline.com/doi/ pdf/10.1080/00378941.1927.10833641?needAccess=true

11. Publications with mention of Herbarium collections of Odessa I.I Mechnikov National University (MSUD) URL: http://onu.edu.ua/en/structure/faculty/bio/herbarium-national-heritage/publications-with-mention-of-herbarium-collections-f-odessa-i-i-mechnikov-national-university-msud 
С. Г. Коваленко, Т. В. Васильсва ${ }^{1}$, О. Ю. Бондаренко, В. В. Немерцалов ${ }^{2}$ Одеський національний університет імені I. I. Мечникова, кафедра ботаніки вул. Дворянська, 2, Одеса, 65082, Україна, e-mail: tvas@ukr.net ${ }^{1}$; wism@ukr.net ${ }^{2}$

\section{КОЛЕКЦІЯ ВІДОМОГО БОТАНІКА МІШЕЛЯ ГАНДОЖЕ \\ У ГЕРБАPIÏ MSUD (до святкування року Франції в Україні)}

प

Метою досліджень був аналіз гербарних зборів французького вченого Мішеля Гандоже - відомого ботаніка XIX ст., які зберігаються в історичному гербарії Одеського національного університету імені I. I. Мечникова (MSUD), що включено до переліку об'єктів, які становлять Національне надбання України.

У завдання досліджень входило: провести систематичний аналіз видів, представлених в колекції, виявити місця збору рослин, оприлюднити біографічні відомості щодо життя та наукової діяльності М. Гандоже.

Матеріалом для дослідження були гербарні збори М. Гандоже 1895-1898 pp. 3 півдня Франції, які є частиною іменної колекції Е.Е. Ліндеманна.

Таксономічну належність рослин наведено за номенклатурою того часу, назви населених пунктів цитуються згідно інформації, що представлена на етикетках. Використовували класичні загальновідомі методи аналізу гербарних колекцій.

Результати. Мішель Гандоже присвятив своє життя вивченню флори Середземномор'я, особливо Іспанії, куди він здійснив 24 наукові подорожі, був одним 3 перших описувачів флори Іберії. Крім Іспанії, він збирав гербарій у Греції, Португалії, Алжирі. У 1883-1891 pр. підготував європейську флору у 27 томах. Зібраний ним гербарій рослин світу нараховує 800 тисяч аркушів.

Висновок. В історичному гербарії Е. Е. Ліндеманна представлено 332 аркуші зборів М. Гандоже з узбережжя Рони (Rhone) та з Арні, Систематичний склад рослин зазначеної колекції включає 318 видів та 26 форм з 198 родів та 60 родин. 14 гербарних аркушів $є$ автотипами.

Ключові слова: гербарій Одеського національного університету імені I.I. Мечникова (MSUD), історія науки, Мішель Гандоже.

\section{References}

1. Alekseev E. B., Gubanov I. A., Tikhomirov V. N. (1989) Botanical nomenclature [Botanicheskaya nomenklatura], M.: Izd-vo MGU, $168 \mathrm{~s}$.

2. Herbarium' collection by E.E. Lindemann (2017) [Herbarna Kolektsiia E. E. Lindemanna] Uklad.: S.G. Kovalenko, O.Yu. Bondarenko, T.V. Vasylyeva, V.V. Nemertsalov, Odesa : Osvita Ukrainy, $776 \mathrm{~S}$.

3. Library of the Botanical Garden, University of Padua, Italy- URL: https://archive.org/details/MGandoger-recto-PHAIDRA_o_1773

4. Gandoger Michael. The ten new plants, especially at the flower European agendas. Second part, published in the Bulletin of the agricultural, scientific and literary Society of Pyrenees-Orientales, 22: 416-459. URL: https://archive.org/details/mobot31753003743520

5. Gandoger Michael. Flora Cretica URL: https://archive.org/details/mobot31753000530409

6. Gandoger Michaele. Flore Lyonnaise and south-ext departments including the analysis of spontaneous plants and plants grown as industrial or ornamental. Paris, Lyon, 1875. 322 s. URL: https://archive.org/details/florelyonnaiseet00gand 
7. Gandoger Michaele. Monograpia. Rosarum Europaea and Orientis. URL: https://archive.org/ details/monographiarosar04 gand/page/n5

8. Gandoger Michael. The new look of the European flora. Systematic OR RELATING omniutn Plants in Europe will hitherto been recognized. Paris, 1910. 542 s. URL: https://archive.org/ details/novusconspectusf00gand/page/n5

9. IPNI. URL: https://www.ipni.org/a/3009-1; https://www.ipni.org/?q=author\%20std\%3AGand.

10. Abbot J.-B. Charbonnel (1927) Abbot Michel Gandoger, Bulletin of the Botanical Society of France, 74: 1, 3-11, DOI: 10.1080/00378941.1927.10833641 https://www.tandfonline.com/doi/pdf/10.1080/00378941.1927.10833641?needAccess=true

11. Publications with mention of Herbarium collections of Odessa I.I Mechnikov National University (MSUD) URL: http://onu.edu.ua/en/structure/faculty/bio/herbarium-national-heritage/ publications-with-mention-of-herbarium-collections-f-odessa-i-i-mechnikov-national-universitymsud. 